\section{An Active Approach to Teaching the Political Economy of Development}

\author{
Joseph G. Bock, William Jewell College \\ D. Dean Dunham, Jr., William Jewell College
}

The scene is familiar. The student to your left is expounding upon an esoteric interpretation of Marxist theory. The student on your right looks confused and then, after getting enough courage, says, "I'm sorry, maybe I'm the only ignorant one in here but, what really is socialist development?" Another student, near the back of the room, keeps nodding off, struggling to stay awake.

Because of the diversity in student backgrounds, discussions of the political economy of development in a classroom setting can be unsatisfying. Some students, familiar with the writings of classical political economists, tend to dominate the discussion; others feel shrouded in ignorance and, hence, reluctant to participate.

The two of us teach an interdisciplinary course, offered for both social science and humanities credits, which focuses on how the United States influences developing countries. We have found it crucial that students become familiar with the meaning of development, as viewed from different perspectives, prior to discussing the history and motivations of U.S. foreign policy.

We have employed an "active learning" teaching methodology in our course and find it effective in keeping students interested. ${ }^{1}$

The course was organized into three segments, each of which focuses on a theory of development. Students were assigned readings from a book by James Weaver and Kenneth Jameson; we began with the orthodox/classical view, moved to the growth-with-equity paradigm, and ended with dependency theory and the radical political economy perspective. These were three sequenced, separate exercises, as identified in the comprehensive schedule in the appendix.

We divided our method of approaching each segment into four distinct phases-exposure, discussion, performance, and reflection.

During the exposure phase, a lecture format was used. For example, while presenting the orthodox/ classical view, we introduced basic concepts such as capital accumulation, government enforcement of contracts, savings rates, and the philosophical bases of private property. We consider the exposure phase necessary for the sake of comprehensive coverage. However, it should be kept to a minimum, and other approaches should also be employed, as we recommend in the discussion phase, as a hedge against some students' feeling overwhelmed, disinterested, or intimidated because a number of their colleagues have more background in the subject.

We should note that, besides limiting the duration of the early lecture/ questions/comments exposure phase, we broadened the students' useable knowledge and experience base with humanities readings prior to this development theory, social science module. This provided tangible hooks for students to hang theoretical information.

The discussion phase converted asymmetrical knowledge of political economy into a learning advantage. Less knowledgeable students learned from those more familiar with the theory but also questioned doctrinaire assumptions.

To add energy to their discussion, we broke the students into small groups with an assignment to motivate them to pursue the theory with missionary zeal. We surprised them with this announcement:

\section{Conference of Orthodox Theorists}

Welcome to the conference of orthodox theorists. We have a grave task before us. As you know, the purpose of this conference is to identify how to preserve our nation's political and economic health.
Our government currently is traveling down the wrong path. It is inconceivable that our lawmakers are now considering a number of ill-advised and, I would add, damaging proposals. If we are ever to get ourselves out of the stigma of being a socalled Third World country, we must invoke political and economic discipline. It is our job-indeed, our duty-to respond, as a society of orthodox theorists, to at least the five major radical policies under consideration:

1. The legalization of workers' strikes;

2. A nation-wide program that provides for guaranteed foodstuffs, such as bread, for the entire population;

3. The nationalization of certain industries, such as our railroads and electrical companies;

4. A heavy income tax on the wealthy; and

5. Protectionist barriers on textile products not developed within our country.

I am asking that you form into five groups, each developing cogent arguments against one of these outrageous proposals. I would also ask that you keep in mind your fidelity to orthodox principles.

You have twenty minutes before we reconvene. A representative of your group will be given three minutes to deliver a speech to the entire conference, thereby allowing us collectively to develop the understanding necessary for immediate, persuasive action against these outlandish governmental proposals.

Please break up into your groups now.

In preparing to present their conclusions to the class, students displayed intellectual curiosity and creative introspection. The nature of the assignment elicited their strong desire to perform well in front of their classmates.

The performance phase, when each group presented their results to the entire class, was full of laughter and applause. ${ }^{2}$ Classmates made jeering comments of support as the group representatives delivered their recommendations to the conference, some with passionate speeches. By this 
FIGURE 1

Comparative Matrix Rating System for Growth-With-Equity Approaches
Low
3

High

1. Reduces Unemployment

2. Reduces Income Inequality

3. Reduces Absolute Poverty

4. Realistic

5. Promotes Economic Growth

6. Increases Political Participation

7. Minimizes Likelihood of Civil Violence

Approaches

Total Score

Employment Generation/Appropriate Technology

Redirecting Investment

Meeting Basic Needs

Human Resource Development

Agricultural and Rural Development

New International Economic Order

time, the students had assimilated and applied the theory.

We found that a final, reflective phase was also necessary. A number of concepts are normally clarified during presentations to the class. It is incumbent upon instructors to make note of those concepts and briefly discuss them after the presentations. In our case, for instance, students had made the connection between savings, reinvestment, capital accumulation, and economic growth, but we clarified it further with a cyclical chart on the chalkboard to sharpen their understanding.

It is also important to debrief during the reflection phase. Emotional discomfort with a new concept should be discussed. Our students, for instance, obviously wanted to talk about the question of whether it was beneficial for society, in the long run, to assist the poor and unemployed.

During the next segment, dealing with the growth-with-equity paradigm, we began the exposure phase by briefly explaining all six approaches discussed in the Weaver and Jameson book. This was followed by comparing those approaches using a rating system of ordinal values, derived through a democratic process conducted in quasi-parliamentary fashion. This matrix was put on the chalkboard, and each of the six approaches was scrutinized with it (see Figure 1).

At the end of the discussion on each approach, the values for each category were totaled, providing a crude indicator for an overall class evaluation of which strategy they considered to be the best.

During the following class period, after the students had gotten broad exposure through the comparative matrix exercise, we made another announcement:

\section{Conference of Enlightened Theorists}

Welcome to the conference of Enlightened Theorists! Before we begin, let's take a moment to pause and think about the Society of Enlightened Theorists' growth-with-equity creed: that we will seek to reduce unemployment in the developing world; to reduce income inequality; and, most importantly, to reduce absolute poverty.

The reason for this conference is clear. At a recent conference of orthodox theorists, we were attacked: our motives were attacked; our intellectual honesty was attacked; and, our methodological integrity was attacked.

As you know, we have been constrained for a number of years now to six growth-with-equity approaches. As enavenues of equitable development.

We must identify workable solutions for the world's poor, and we also must, oh, how should I say this, put those lightened theorists we must develop orthodox theorists "in their place"!

I appreciate your dedication to the cause shown through your attendance today. Now, I would like to ask that you break up into five small groups. Your objective is to develop a new growthwith-equity approach. After twenty minutes, we will reconvene and hear a representative from each group present the various new growth-with-equity strategies. Remember our creed: reduce unemployment, income inequality and absolute poverty.

And let's put those orthodox theorists right back into their conservative straight jackets where they belong!

After these small group presentations, we found that, during the reflection phase, it was critical to compare and contrast the various growth-with-equity approaches. For instance, how does a basic needs strategy combine with a human resource development approach? Would it be advisable for the government to pursue a basic needs approach, establish a minimum level of public welfare, then embrace a human resources development policy?

We chose to cover the segment focusing on dependency theory and radical political economy more substantially during the exposure phase and then combine it into an overall active learning exercise. After three class periods of lecture/questions/ comments on radical political economy and dependency theory, a final announcement was made:

\section{Political Economy Conference}

I would like to welcome you here today and want to personally thank you for having the fortitude to attend this conference. We all feel passionately about development in the Third World, but that does not excuse our unprofessional behavior in making accusations about other theorists.

Shame on us!

This conference is designed to allow each respective group of theorists to respond to the accusations that have been leveled at them. Certainly, if you have other criticisms that you would like to address, by all means do so.

If you feel emotional, then assert yourself. This conference is supposed to help us get our feelings as well as our theories out into the open.

Now, please divide into four groups: orthodox/classical, growth-with-equity, 
dependency, and radical political economy theorists. Your objective is to defend your paradigm. In twenty minutes, each of the groups must designate a representative or have a number of representatives perform your rebuttal of the accusations leveled at you.

\section{Handout for the Political Economy Conference}

\section{Accusations Leveled at}

Orthodox Theorists

- Results of this approach have been an increase in unemployment, income inequality, and absolute poverty.

- The "trickle down" effect is a wishful fiction.

- The market mechanism does not take into account human suffering.

\section{Accusations Leveled at}

\section{Growth-with-Equity Theorists}

- These approaches are purely pie-inthe-sky dreams of some academics who are not willing to admit that development is a brutal process.

- The presumption that significant land reform is possible assumes that countries have just fought a major war or revolution that created a political environment conducive to such reform (look at the experiences of Japan and Taiwan compared to so-called land reform in South Vietnam and El Salvador).

- Approaches focused on satisfying basic needs simply breed a welfare mentality and create societal expectations of government services which, if not satisfied, can lead to relative deprivation and eventually civil violence.

\section{Accusations Leveled at Dependency Theorists}

- Dependency theory is simply a tool of Third World leaders and academics to evade their own responsibilities by blaming the rest of the world for their own problems. Developing countries need to get their own "houses in order."

- The Newly Industrializing Countries (NICs) have refuted dependency theory by their collective counterexample. Rather than insulating themselves from the international system as a method of development, they have instead integrated themselves into it by increasing foreign trade.

- Multinational corporations can be "engines of growth" by bringing in foreign capital and technology.
Accusations Leveled at

\section{Radical Political-Economy Theorists}

- Obviously, centrally planned economies do not work. Capitalism and democracy are "breaking out" all over the world.

- The idea that socialist development brings with it greater income equality is a sham. Look at the Soviet experience.

- Socialist development is too brutal. Again, take a look at the U.S.S.R. and their "liquidation" of thousands of middle-income farmers-a government systematically killing its own people!

- Collectivization of agriculture has been an abysmal failure.

Late in the course when we focused on extended fictional work, it was evident that the students could apply the paradigms. For instance, there was a lengthy student-initiated discussion as to whether Artemio Cruz (the main character in Carlos Fuentes' novel, The Death of Artemio Cruz) was the type of capitalist envisioned by orthodox theory. They concluded that, for the most part, he was, but that his foreign investments and threats to government officials to take his money out of Mexico was not ideal reinvestment behavior-clearly one of the problems pointed out by dependency theorists. $^{3}$

Instructors who want their students to develop a more extensive grasp of development theory will need to expand upon this schedule. Our approach provides basic understanding in a condensed time frame.

\author{
APPENDIX \\ Schedule (Assuming a 50-minute class period) \\ Segment 1 \\ Day 1: Students should have read pages 1-44 in Weaver and Jameson \\ Lecture on the orthodox/classical paradigm \\ Day 2: Conference of orthodox theorists \\ 5 minutes-Announcement to the class \\ 20 minutes-Small group discussion \\ 15 minutes-Group presentation ( 3 minutes per group) \\ 10 minutes-Reflective discussion
}

Segment 2

Day 3: Students should have read pages 45-78 in Weaver and Jameson and the article by Adelman

Lecture on the growth-with-equity paradigm

Day 4: Class discussion on growth-with-equity using the comparative matrix

Day 5: Conference of Enlightened Theorists

5 minutes-Announcement to the class

20 minutes-Small group discussion

15 minutes-Group presentations ( 3 minutes per group)

10 minutes-Reflective discussion

Segment 3

Day 6: Students should have read pages 79-121 in Weaver and Jameson

Lecture on the radical political economy paradigm and dependency theory

Day 7: Class discussion on the radical political economy paradigm

Day 8: Class discussion on dependency theory

Day 9: Political Economy Conference

5 minutes-Announcement

20 minutes-Small group discussion (with handouts)

15 minutes-Group presentations (close to 4 minutes per group)

10 minutes-Reflective discussion 


\section{Notes}

1. For an interesting explanation of the active learning approach, see Frederick (1989).

2. It is hoped that during the discussion and performance phases that instructors are able to accomplish what P. J. Palmer describes as "hearing people into speech" by creating a situation in which they are "committed to serious [albeit, sometimes humorous] listening." See Palmer (1990).

3. See Fuentes (1990: 134-35).

\section{References}

Adelman, I. 1975. "Growth, Income Distribution and Equity Oriented Development Strategies." World Development : 67-76.

Frederick, P. J. 1989. "Involving Students More Actively in the Classroom." In The Department Chairperson's Role in Enhancing College Teaching, ed. A. F. Lucus. San Francisco: Jossey-Bass, 31-40.

Fuentes, C. 1990. The Death of Artemio Cruz. New York: The Noonday Press.

Palmer, P. J. 1990. "Good Teaching: A Matter of Living the Mystery." Change 22: 15 .

Weaver, J. and K. Jameson. 1981. Economic Development: Competing Paradigms. Lanham, MD: University Press of America.

\section{About the Authors}

Joseph G. Bock

Joseph G. Bock is an adjunct instructor of political science at William Jewell College. He also serves in the Missouri General Assembly and is

Chairman of the

House Energy and Environment Com-

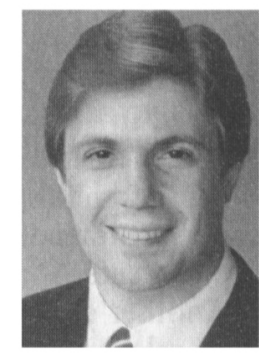
mittee. He is the author of The White House Staff and the National Security Assistant: Friendship and Friction at the Water's Edge (Westport, CT: Greenwood Press, 1987).

D. Dean Dunham, Jr.

D. Dean Dunham, Jr. is professor of English and chairman of the English Department at William Jewell College. He also serves as faculty instructional aide for the college.

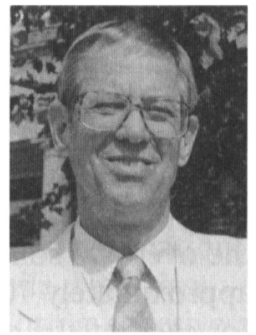

\section{The Political Science Course Syllabi Project Selections from the Editors' Introductions to Five Introductory Course Collections}

The APSA is conducting a project to collect and distribute exemplary syllabi for ten political science courses. The project is supported by a grant from the Fund for the Improvement of Postsecondary Education. In fall 1991, collections were prepared for introductory courses. The editors and contributors to each syllabi collection were listed in the March 1992 issue of PS: Political Science \& Politics, pp. 109-11.

Five additional syllabi collections are being completed this fall. A list of the contributors to each collection, accompanied by selections from the editors' introductions, will be featured in the March 1993 issue of $P S$. The course collections and their editors are:

Methodology, edited by John R. Freeman and W. Phillips Shively, University of Minnesota

Political Behavior, edited by Nancy Zingale, University of St. Thomas
Public Administration, edited by Naomi Lynn, Sangamon State University

Public Law, edited by Lief Carter, University of Georgia

Senior Seminar/Capstone Course, edited by Ronald Kahn, Oberlin College

To provide faculty with additional information about the introductory course syllabi collections, we are publishing selections from their editors' introductions. The editors' comments we feature reveal significant differences among the courses that reflect both the level of theoretical order in the discipline and the contribution of a course to the undergraduate curriculum. We invite faculty and graduate students to review all of the course syllabi collections in their entirety. Information about how to do so follows the editors' commentaries.

\section{General Introductory Courses in Political Science ("Introduction to Political Science," "Introduction to Politics [\&/or] Government”)}

\author{
John C. Wahlke \\ University of Arizona
}

Almost every liberal arts student's first collegiate view of the discipline of political science and its subject matter is the course syllabus handed to him the first day of class in his first political science course. We who teach students in those first encounters ought to pay attention to what, if anything, students can or should learn from reading that syllabus.

Political science differs markedly from other social and behavioral science disciplines in the way students are introduced to their subject. To begin with, a general Introduction to Political Science (or Government 